ISSN 0258-7122 (Print), 2408-8293 (Online)

Bangladesh J. Agril. Res. 43(3): 369-381, September 2018

\title{
ANTIOXIDANT POTENTIALS OF DIFFERENT POTATO GENOTYPES
}

\author{
S. M. Z. Al-MeraJ ${ }^{1}$, T. K. GHOSH ${ }^{2}$ A. K. M. A. ISLAM ${ }^{3}$ \\ AND M. MOHI-UD-DIN ${ }^{4}$
}

\begin{abstract}
The present investigation was undertaken to analyze the antioxidant potential of sixteen different potato genotypes. Eleven yellow fleshed potato genotypes namely Forza, Courage, Laura, Rosa Gold, Lady Rosetta, Cumbica, Asterix, Coronada, Granola, Cardinal and Diamant and five purple fleshed potato genotypes namely Jam Alu, KAC 10063, KAC 10064, KAC 10069, KAC 10097 were used as experimental materials. Total carotenoids, anthocyanin, phenolics, flavonoids, ascorbic acid and antioxidant activity in the above mentioned genotypes were determined to compare the antioxidant potentials of the genotypes. Analysis of above mentioned parameters resulted significant variation in their contents in both yellow and purple fleshed genotypes. The results indicate the purple fleshed genotypes showed significantly higher carotenoids, anthocyanin, flavonoids and total antioxidant activity than those of yellow fleshed genotypes. The findings also suggested the antioxidant activity of the genotypes positively correlates to the total content of carotenoids, anthocyanin and flavonoids. Since, purple fleshed genotypes showed higher antioxidant properties, the results of this study claim that the purple fleshed genotypes would be suitable for direct consumption as vegetables which might increase the health and food security of human beings.
\end{abstract}

Keywords: Potato, anthocyanin, phenolics, carotenoids and flavonoids.

\section{Introduction}

Potato, the fourth most producing (376 million tons) important food crop after maize, wheat and rice (FAOSTAT, 2016), is primarily considered as a source of carbohydrate, but recent studies propose that it has high nutritional value due to the presence of natural bioactive compounds including cellular antioxidants. Potato is consumed as the major vegetable in developing country like Bangladesh where annual demand of potato is greater than 7.0 million tons against its production of 9.4 million tons (BBS, 2016). The people of Bangladesh mostly consume white fleshed potatoes though very few people are interested to coloured fleshed genotypes due to having their good nutritional value. A lot of investigations concerning growth, yield, nutritional and physiological properties of potato genotypes throughout the world have been found, but very few claims

${ }^{1}$ Lecturer, Dept. of Crop Botany, Bangabandhu Sheikh Mujibur Rahman Agricultural University (BSMRAU), ${ }^{2}$ Associate Professor, Dept. of Crop Botany, BSMRAU, ${ }^{3}$ Professor, Dept. of Genetics and Plant Breeding, BSMRAU, ${ }^{4}$ Assistant Professor, Dept. of Crop Botany, BSMRAU, Bangladesh. 
have been reported on the crucial biochemical properties such as antioxidant potentials of the genotypes. Moreover, very little efforts are made with coloured potatoes which likely to be the good source of antioxidants and good for human health. Studies have indicated that antioxidants have high free-radical scavenging activity, which helps reduce the risk of chronic diseases including cancer and age-related neuronal degeneration (Teow et al., 2007). Investigations suggest that antioxidant activity in coloured potatoes is associated with the presence of different phytochemicals such as polyphenols, anthocyanins, flavonoids, carotenoids, ascorbic acid, tocopherols, alpha-lipoic acid and selenium (Kosieradzka et al., 2004; Lachman et al., 2009). Several findings also suggest that purple potatoes contain anthocyanin and phenolics and show high antioxidant activity than that of red, yellow and white potato cultivars indicating the potentials of coloured potato genotypes in human health security (Jansen and Flamme, 2006). Investigations on the above issues have been reported throughout the world, but very few claims are made so far in the country like Bangladesh where potato is consumed as the major vegetable crop. Hence, along with carbohydrate, the antioxidant rich coloured genotypes should be explored to meet the additional health security. Considering the facts, in the present efforts, sixteen potato genotypes comprising both yellow and purple fleshes were taken into consideration to analyze them to find out antioxidant rich genotypes which might fulfill the basic requirements as direct consumption and food security regarding to health concern issue.

\section{Materials and Methods}

\section{Plant materials}

Sixteen potato genotypes namely Forza, Courage, Laura, Rosa Gold, Lady Rosetta, Cumbica, Asterix, Coronada, Granola, Cardinal and Diamant of yellow flesh and Jam Alu, KAC 10063, KAC 10064, KAC 10069, KAC 10097 of purple flesh were used as experimental material. The materials were collected from Bangladesh Agricultural Research Institute (BARI), Bangladesh Agricultural Development Corporation (BADC) and local areas of Gazipur. Randomized Complete Block Design with three replications was used as experimental design Potato genotypes were planted in the experiment field on 25 November 2015 and the tubers were harvested at 90 DAP (Days after Planting) and kept in room temperature for curing. Chemical analyses were performed in the Crop Botany laboratory of Bangabandhu Sheikh Mujibur Rahman Agricultural University.

\section{Total carotenoids}

Total carotenoid content was determined spectrophotometrically according to the procedure of Lachman et al. (2003) with slide modifications. Briefly, $1 \mathrm{~g}$ of potato sample was taken into a glass vial and $5 \mathrm{ml}$ of acetone was added and kept 
at $4^{\circ} \mathrm{C}$ in the dark for 24 hours. Using the supernatant absorbance was measured at $444 \mathrm{~nm}$ and total carotenoid content was expressed as micrograms of lutein equivalent per gram of fresh weight sample $\left(\mu \mathrm{g} \mathrm{LE} \mathrm{g}^{-1} \mathrm{FW}\right)$ for three replications from the lutein standard curve.

\section{Anthocyanin content}

Anthocyanin content was determined spectrophotometrically as described by Hughes and Smith (2007) with slide modifications. For preparing the extraction solution, 6M HCL was added into a volumetric flask where methanol and distilled water were taken earlier. Fresh potato sample was taken into an ice cold vial and extraction solution was added here. After keeping the vial at $4{ }^{\circ} \mathrm{C}$ for 24 hours, $2 \mathrm{ml}$ of the solution was centrifuged with distilled water and chloroform. The aliquot was taken into a cuvette and absorbance was measured at $530 \mathrm{~nm}$. The anthocyanin content was expressed as micrograms of cynadin-3-glucoside equivalent per gram of fresh potato sample.

\section{Extraction and determination of polyphenol, flavonoid content and antioxidant activity}

The extraction was done by following the procedure of Nayak et al. (2011). Peeled and chopped potato flesh was homogenized with methanol (HPLC grade) to a uniform consistency by mortar and pestle. The samples were centrifuged at $30,000 \times \mathrm{g}$ at $4^{\circ} \mathrm{C}$ for $20 \mathrm{~min}$ and the supernatants stored at $-20^{\circ} \mathrm{C}$ for further analysis of total phenolics, flavonoids and total antioxidant activity.

The content of total phenolic compounds was determined spectrophotometrically according to the Folin-Ciocalteu method (Singleton et al., 1999). $1.0 \mathrm{ml}$ of methanolic extract sample was taken into test tubes and $0.5 \mathrm{ml} 10 \%(0.2 \mathrm{~N})$ Folin-Ciocalteu's reagent was added here. After a 15 minutes of incubation period, $2.5 \mathrm{ml}(700 \mathrm{mM}) \mathrm{Na}_{2} \mathrm{CO}_{3}$ solution was mixed and incubated at room temperature for 2 hours. The absorbance of reaction solutions was measured at $765 \mathrm{~nm}$ against a blank sample. The measurements were compared to a standard curve of gallic acid solutions and expressed as micrograms of gallic acid equivalents per gram fresh weight ( $\left.\mu \mathrm{g} \mathrm{GAE} \mathrm{g}^{-1} \mathrm{FW}\right)$.

Total flavonoid content was determined according to the procedure of Zhuang et al. (1992) with slide modification. Briefly, $1 \mathrm{ml}$ methanol was added to potato extracts into a test tube. Following that, $1 \mathrm{ml}$ of distilled water, $5 \%$ sodium nitrite and $10 \% \mathrm{AlCl}_{3} .6 \mathrm{H}_{2} \mathrm{O}$ were added to the mixture. $2 \mathrm{ml}$ of $1 \mathrm{M} \mathrm{NaOH}$ was added into the test tube at $6^{\text {th }}$ minute. The volume was made $10 \mathrm{ml}$ using distilled water and absorbance was measured at $510 \mathrm{~nm}$ against the blank. Total flavonoid content was expressed as micrograms of quarcetin equivalent per gram of fresh 
weight sample ( $\mu \mathrm{g} \mathrm{QE} \mathrm{g}^{-1} \mathrm{FW}$ ) for three replications from the quarcetin standard curve.

The antioxidant activity of potato samples was determined using the DPPH radical-scavenging assay based on the ability of antioxidants to block the 2, 2Diphenyl-1picrylhydrazyl radical (Brand-Williams et al., 1995). Plant extract and standard were taken into a test tube. After adding $\mathrm{DPPH}^{\circ}$ solution into the test tubes, they were incubated for $5 \mathrm{~min}$ at $25^{\circ} \mathrm{C}$ and finally the absorbance was measured at $517 \mathrm{~nm}$. The antioxidant activity was expressed as $\mathrm{DPPH}^{\circ}$ scavenging percentage $(\%)$.

\section{Extraction and determination of ascorbic acid}

From tuber sample, ascorbic acid was extracted by using $4 \%$ Trichloro Acetic Acid and the supernatant of the potato extract was treated with a pinch of activated charcoal and kept for 5 minutes. Charcoal particles were removed by centrifugation (2,000 rpm for $10 \mathrm{~min})$ again and aliquots were used for Ascorbic acid estimation. Extraction was added with 4\% TCA, DNPH (Dinitrophenyl hydrazine) reagent and thiourea by following the method of Kapur et al. (2012). After incubation $\left(37^{\circ} \mathrm{C}, 3 \mathrm{hrs}\right), 85 \%$ sulphuric acid was added to the cooled sample. Absorbance was read at $540 \mathrm{~nm}$ against blank.

\section{Data Analysis}

Statistical analysis was performed using MSTAT-C software and data were subjected to analysis of variance for mean comparison using Randomized Complete Block Design with three replications. Significant differences were calculated according to Duncan's multiple range test (DMRT) at $\mathrm{p}<0.05$ and data were reported as mean \pm standard error.

\section{Results and Discussion}

\section{Total carotenoids ( $\mu \mathrm{g} \mathrm{g}^{-1} \mathbf{F W}$ )}

Carotenoids act as essential component to increase antioxidant potentials of any vegetable. We determined total carotenoids in different potato genotypes and found a great variation among them (Fig.1). The carotenoid content ranged between 0.47 to $3.00 \mu \mathrm{g} \mathrm{g}^{-1}$ of fresh tuber sample. The purple fleshed genotypes contained higher amount of carotenoids compared to the yellow fleshed genotypes. Among all the genotypes, KAC 10097 showed the highest amount $\left(3.00 \mu \mathrm{g} \mathrm{g}^{-1} \mathrm{FW}\right)$ of total carotenoids. KAC 10063, KAC 10064, KAC 10069 and Jam Alu were found to gain 2.56, 2.51, 2.09 and $1.34 \mu \mathrm{g} \mathrm{g}^{-1} \mathrm{FW}$, respectively. Among the yellow fleshed potato genotypes, Rosa Gold contained $2.78 \mu \mathrm{g} \mathrm{g}^{-1}$ FW and performance of which was very similar to purple fleshed genotypes. Coronada and Cumbica are statistically similar and contained 1.88 and 
$1.79 \mu \mathrm{g} \mathrm{g}^{-1} \mathrm{FW}$, respectively and significantly different from Courage, Forza, Laura and Granola. Some findings also made consistency to our results such as Brown et al. (2005) reported that the light yellow potato cultivars contained 1.01 to $2.71 \mu \mathrm{g} \mathrm{g}^{-1} \mathrm{FW}$ total carotenoids. The total quantity of the carotenoids was found to be between 0.38 and $1.75 \mu \mathrm{g} \mathrm{g}^{-1} \mathrm{FW}$ in eight commercial potato varieties (Breithaupt and Bamedi, 2002). Several investigations showed higher content of total carotenoids in yellow fleshed potatoes than that of white or creamy fleshed potatoes (Andre et al., 2007b, Burgos et al., 2009). From the above result, the findings suggest that the purple fleshed potatoes contain higher amount of carotenoids than that of the yellow color genotypes except the golden yellow coloured Rosa Gold (Fig. 1).

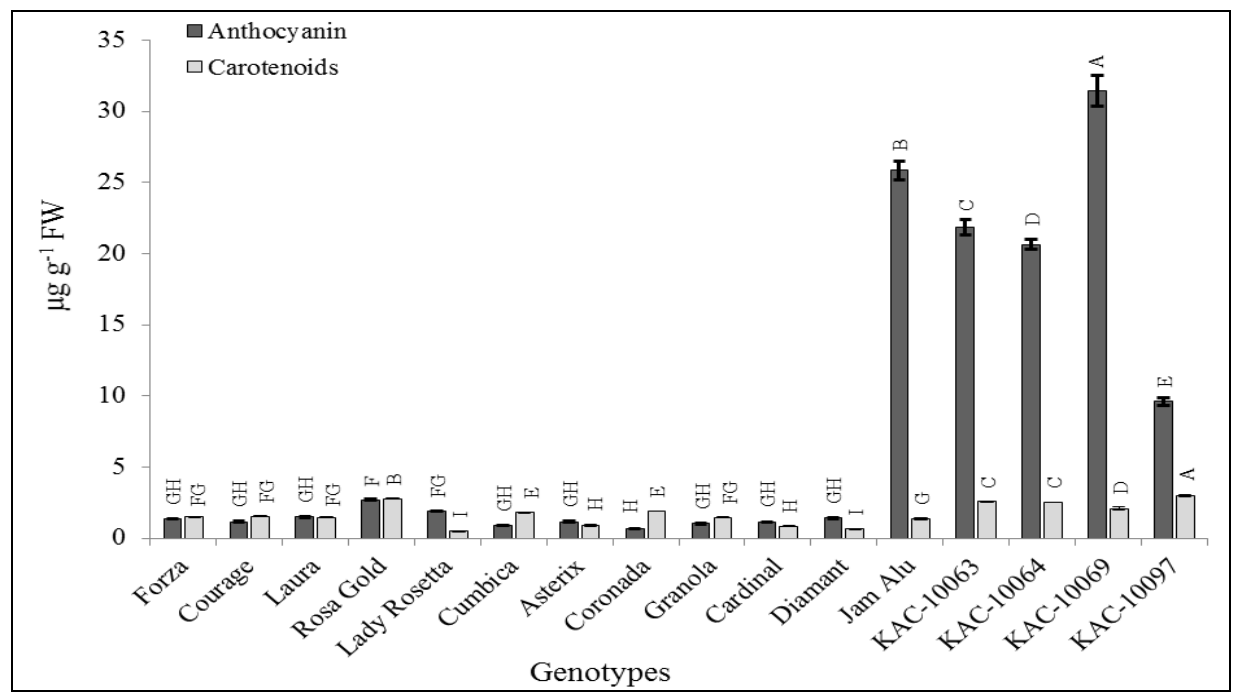

Fig. 1. Anthocynin and carotenoids of sisteen potato genotypes. Vertical bars represent $\pm \mathrm{SE}$ values calculated from three replications; values in the same coloured columns with different letters(s) are significantly different at p $<0.05$ by DMRT.

\section{Anthocyanin $\left(\mu \mathrm{g} \mathrm{g}^{-1} \mathrm{FW}\right)$}

Anthocyanin, a valuable component which have the ability to trigger the antioxidant potential of plant materials. Hence, we compared the anthocyanin content in different potato genotypes. In this finding, the anthocyanin content of potatoes ranged from 0.65 to $31.45 \mu \mathrm{g} \mathrm{g}^{-1}$ of fresh weight sample. Like carotenoids, anthocyanin content is also higher in the purple fleshed potato genotypes (Fig. 1). The highest amount $31.45 \mu \mathrm{g} \mathrm{g}^{-1}$ was found in KAC 10069 followed by Jam Alu, 25.83; KAC 10063, 221.84; KAC 10064, 20.63 and KAC 10097, $9.60 \mu \mathrm{g} \mathrm{g}^{-1} \mathrm{FW}$ (Fig. 1). Yellow fleshed genotypes comprised with lower amount of anthocyanin compared to the purple fleshed potatoes and ranged from 
0.65 to $2.69 \mu \mathrm{g} \mathrm{g}^{-1} \mathrm{FW}$. Rosa Gold and Lady Rosetta are statistically similar and contained 2.69 and $1.19 \mu \mathrm{g} \mathrm{g}^{-1} \mathrm{FW}$. There was no significant difference found among the content of Laura, Diamant, Forza, Courage, Asterix, Cardinal, Granola, Cumbica and Coronada (Fig. 1). According to Kita et al. (2015), the anthocyanin content of potatoes ranged from 6.7 to $13.0 \mathrm{mg} 100 \mathrm{~g}^{-1} \mathrm{FW}$ (67 $130 \mu \mathrm{g} \mathrm{g}^{-1}$ ) in purple fleshed tubers. In the present study, almost all genotypes exhibited decreased anthocyanin content which might be the effect of different genotypic and growing conditions. Leszczynski (2000) stated that the most important factor responsible for variation in anthocyanin content is genotype, along with the climate, location and storage conditions.

\section{Flavonoids $\left(\mu \mathrm{g} \mathrm{g}^{-1} \mathrm{FW}\right)$}

We also determined flavonoids content which is also considered as valuable components for increasing antioxidant activity. Likewise carotenoids, anthocyanin content in the studied genotypes, flavonoid content of purple fleshed potato genotypes were much higher than those of yellow fleshed potatoes (Table 1). Flavonoid content of purple fleshed genotype ranged from 49.59 to $175.70 \mu \mathrm{g}$ $\mathrm{g}^{-1} \mathrm{FW}$. The highest amount was found in KAC $10069\left(175.70 \mu \mathrm{g} \mathrm{g}^{-1} \mathrm{FW}\right)$. KAC 10063, KAC 10097, KAC 10064 and Jam Alu contained 167.10, 160.20, 158.30 and $49.59 \mu \mathrm{g} \mathrm{g}^{-1} \mathrm{FW}$, respectively, and they are statistically different from each other. Brown (2006) found up to $30 \mu \mathrm{g} 100 \mathrm{~g}^{-1} \mathrm{FW}$ of flavonoids present in the white-flesh potatoes with roughly twice the amount present in purple-flesh potatoes that supports the findings of the present study. In this study, yellow fleshed genotypes showed lower performance in respect to flavonoid content than purple fleshed potatoes. Among yellow fleshed genotypes, highest amount of flavonoids accumulation was found in Rosa Gold $\left(50.87 \mu \mathrm{g} \mathrm{g}^{-1} \mathrm{FW}\right)$ followed by Asterix (40.55 $\left.\mu \mathrm{g} \mathrm{g}^{-1} \mathrm{FW}\right)$, Cardinal $\left(36.82 \mu \mathrm{g} \mathrm{g}^{-1} \mathrm{FW}\right)$ and Diamant $\left(32.77 \mu \mathrm{g} \mathrm{g}^{-1}\right.$ FW) which are statistically different (Table 1 ).

\section{Ascorbic acid content (Vitamin - C) $\left(\mu \mathrm{g} \mathrm{g}^{-1} \mathrm{FW}\right)$}

Ascorbic acid has antioxidant potential which is necessary for scavenging activities against the free radical produced within the human body. So it has a high nutritive value in our daily foods and estimation of ascorbic acid is very crucial in popular vegetable potato. In this experiment, range of ascorbic acid content was found from 37.42 to $164.70 \mu \mathrm{g} \mathrm{g}^{-1}$ fresh potato sample for yellow fleshed genotypes (Table 1). The highest value; $164.70 \mu \mathrm{g} \mathrm{g}^{-1} \mathrm{FW}$, was found in Coronada, following Diamant; $140.30 \mu \mathrm{g} \mathrm{g}^{-1}$, and Granola; $100.30 \mu \mathrm{g} \mathrm{g}^{-1}$ fresh potato which were statistically different from each other. Rosa Gold contained ascorbic acid $63.62 \mu \mathrm{g} \mathrm{g}^{-1} \mathrm{FW}$ and, the lowest amount $\left(48.58 \mu \mathrm{g} \mathrm{g}^{-1}\right)$ was found for Lady Rosetta (Table 1). Purple fleshed potatoes gained comparatively lower amount of ascorbic acid ranges between $37.42-67.37 \mu \mathrm{g} \mathrm{g}^{-1} \mathrm{FW}$. KAC 10064 
and KAC 10069 contained 67.73 and $67.07 \mu \mathrm{g} \mathrm{g}^{-1} \mathrm{FW}$ without any statistical difference. Other three genotypes Jam Alu, KAC 10097, KAC 10063 showed 50.56; 40.73 and $37.42 \mu \mathrm{g}$ ascorbic acid content $\mathrm{g}^{-1}$ fresh potato respectively (Table 1). Kaur and Aggarwal (2014) described in their findings that ascorbic acid content in Indian and exotic potato genotypes ranged $110-190 \mu \mathrm{g} \mathrm{g}^{-1}$ fresh weight that clearly justifies the result of this research finding.

Table 1. Estimation of flavonoid, ascorbic acid and phenolics of sixteen potato genotypes

\begin{tabular}{|c|c|c|c|}
\hline Genotypes & $\begin{array}{l}\text { Flavonoid } \\
\left(\mu \mathrm{g} \mathrm{g}^{-1} \mathrm{FW}\right)\end{array}$ & $\begin{array}{c}\text { Ascorbic Acid } \\
\left(\mu \mathrm{g} \mathrm{g}^{-1} \mathrm{FW}\right)\end{array}$ & $\begin{array}{l}\text { Phenolics } \\
\left(\mu \mathrm{g} \mathrm{g}^{-1} \mathrm{FW}\right)\end{array}$ \\
\hline \multicolumn{4}{|c|}{ Yellow Fleshed Genotypes } \\
\hline Forza & $10.96 \pm 0.65^{\mathrm{i}-\mathrm{k}}$ & $85.79 \pm 0.51^{\mathrm{d}}$ & $155.1 \pm 4.26^{\mathrm{hi}}$ \\
\hline Courage & $24.86 \pm 0.98^{\mathrm{g}}$ & $59.88 \pm 2.21^{\mathrm{ef}}$ & $304.5 \pm 5.92^{c}$ \\
\hline Laura & $16.38 \pm 0.57 \mathrm{hi}$ & $68.39 \pm 1.46^{\mathrm{e}}$ & $277.7 \pm 7.08^{\mathrm{d}}$ \\
\hline Rosa Gold & $50.87 \pm 2.23^{\mathrm{d}}$ & $63.62 \pm 3.08^{\mathrm{e}}$ & $60.18 \pm 5.02^{\mathrm{k}}$ \\
\hline Lady Rosetta & $5.08 \pm 0.40^{\mathbf{k}}$ & $48.58 \pm 1.55^{\mathrm{gh}}$ & $267.5 \pm 2.68^{\mathrm{d}}$ \\
\hline Cumbica & $11.86 \pm 1.00 \mathrm{ij}$ & $87.11 \pm 2.22^{\mathrm{d}}$ & $168.0 \pm 6.30^{\mathrm{gh}}$ \\
\hline Asterix & $40.55 \pm 1.03^{\mathrm{e}}$ & $80.87 \pm 1.08^{\mathrm{d}}$ & $367.0 \pm 8.06^{\mathrm{b}}$ \\
\hline Coronada & $18.64 \pm 1.20^{\mathbf{h}}$ & $164.70 \pm 6.56^{\mathrm{a}}$ & $212.4 \pm 8.06^{\mathrm{f}}$ \\
\hline Granola & $9.04 \pm 0.93^{\mathbf{j k}}$ & $100.30 \pm 6.96^{c}$ & $305.3 \pm 7.01^{\mathrm{c}}$ \\
\hline Cardinal & $36.82 \pm 1.46$ ef & $52.76 \pm 1.30^{\mathrm{fg}}$ & $241.9 \pm 4.44^{\mathrm{e}}$ \\
\hline Diamant & $32.77 \pm 1.68^{\mathrm{f}}$ & $140.30 \pm 2.19^{b}$ & $270.8 \pm 6.03^{\mathrm{d}}$ \\
\hline \multicolumn{4}{|c|}{ Purple fleshed Genotypes } \\
\hline $\begin{array}{l}\text { Jam Alu } \\
\end{array}$ & $49.59 \pm 0.69^{d}$ & $50.56 \pm 0.64^{\mathrm{f}-\mathrm{h}}$ & $397.2 \pm 6.76^{\mathrm{a}}$ \\
\hline KAC 10063 & $167.10 \pm 5.33^{b}$ & $37.42 \pm 6.11^{\mathrm{i}}$ & $163.6 \pm 6.80^{\mathrm{gh}}$ \\
\hline KAC 10064 & $158.30 \pm 3.86^{c}$ & $67.73 \pm 2.13^{\mathrm{e}}$ & $136.2 \pm 12.68^{\mathrm{ij}}$ \\
\hline KAC 10069 & $175.70 \pm 1.96^{\mathrm{a}}$ & $67.07 \pm 3.39^{\mathrm{e}}$ & $132.8 \pm 14.68^{\mathrm{j}}$ \\
\hline KAC 10097 & $160.20 \pm 1.19^{\mathrm{c}}$ & $40.73 \pm 2.65^{\mathrm{hi}}$ & $182.5 \pm 6.15^{\mathrm{g}}$ \\
\hline
\end{tabular}

$\mathrm{SE}$ value(s) included with the mean was calculated from three replications and letter(s) next to values in a column indicates statistical difference at $p<0.05$ level of significance by DMRT.

\section{Total phenolic content $\left(\mu \mathrm{g} \mathrm{g}^{-1} \mathrm{FW}\right)$}

Fruits and vegetables contain phenolic compound and this phenolics along with anthocyanin content show good antioxidant properties (Wojdylo et al., 2007) which could improve the quality of different ready potato products. Total 
phenolic content of the yellow fleshed potato samples ranged from 60.18 to 367.0 $\mu \mathrm{g} \mathrm{g}^{-1} \mathrm{FW}$. Asterix attained the highest value $\left(367.0 \mu \mathrm{g} \mathrm{g}^{-1} \mathrm{FW}\right)$ for phenolic content followed by Granola (305.3 $\left.\mu \mathrm{g} \mathrm{g}^{-1} \mathrm{FW}\right)$, Courage (304.5 $\left.\mu \mathrm{g} \mathrm{g}^{-1} \mathrm{FW}\right)$, Laura $\left(277.7 \mu \mathrm{g} \mathrm{g}^{-1} \mathrm{FW}\right)$, Diamant $\left(270.8 \mu \mathrm{g} \mathrm{g}^{-1} \mathrm{FW}\right)$ and Lady Rosetta $(267.5 \mu \mathrm{g}$ $\mathrm{g}^{-1} \mathrm{FW}$ ) (Table 1). Among the purple fleshed genotypes Jam Alu obtained the highest value; $397.20 \mu \mathrm{g} \mathrm{g}^{-1} \mathrm{FW}$ followed by KAC 10097, KAC 10063, KAC 10064 and KAC 10063 which were $182.5,163.6,136.2$ and $132.8 \mu \mathrm{g} \mathrm{g}^{-1}$ fresh weight, respectively (Table 1). Kita et al. (2015) observed in his study that, purple potato cultivars are richer source of polyphenols. American purple fleshed potato tubers also contained higher amount of polyphenols, 76-181 $\mathrm{mg}$ of chlorogenic acid $100 \mathrm{~g}^{-1} \mathrm{FW}$ (Reyes et al., 2005) and Andean purple fleshed Guincho Negra variety contained $285 \mathrm{mg} 100 \mathrm{~g}^{-1} \mathrm{FW}$, higher than presented herein (Andre et al., 2007a). The differences in phenolic content accumulation might be due to the variation of environmental conditions, harvesting date, location, genotypic variations etc. which have been shown to be involved in the accumulation of phenolic compounds in different potato varieties (Lachman et al., 2009; Reyes et al., 2005). Specially, the growing environment might be the possible reason for this decreased accumulation of phenolics in potatoes because Hamouz et al. (1999) described in his findings that, higher level of phenolic content was found in the tubers grown where the intensity of coldness is more.

\section{Total antioxidant activity (DPPH` radical scavenging \%)}

The $\mathrm{DPPH}^{\bullet}$ free radical scavenging activity of the potato extract was determined in the potato genotypes here. It is a discoloration assay, which is evaluated by the addition of the antioxidant to a $\mathrm{DPPH}^{-}$(2, 2-diphenyl-1-picrylhydrazyl, crystalline powder of stable free-radical molecules) solution in methanol and the ability to scavenge the stable free radical of $\mathrm{DPPH}^{\circ}$. We found that the antioxidant potential of yellow and purple fleshed potato range remained between 23.90 to $94.63 \%$. KAC 10097 contained the high level of polyphenols and anthocyanins (Fig. 2) was characterized by highest antioxidant activity and that was $94.63 \%$ followed by KAC 10064 (94.60\%), KAC 10063 (93.93\%) and KAC 10069 (93.33\%), respectively. Jam Alu showed antioxidant activity $64.74 \%$, which differs significantly from four other purple fleshed potato genotypes (Fig. 2). Antioxidant potential of yellow fleshed genotype ranges from 23.90 to 51.83 $\%$ of fresh weight. Rosa Gold, Asterix showed antioxidant potential 51.83 and $51.01 \%$ respectively, which are significantly different from Granola $(42.96 \%)$ and other genotypes. Several efforts were also made to determine antioxidant activity in potato genotypes by various ways and found a great variation in respect to genotypes (Hesam et al., 2012; Reddivari et al., 2007). Research findings of Kaur and Aggarwal (2014) exhibited that the range of $\mathrm{DPPH}^{\circ}$ radical scavenging activity in three potato cultivars is $28.80-67.30 \%$ which is more or less justifiable to our investigations although the results of present study showed better performance than that. 


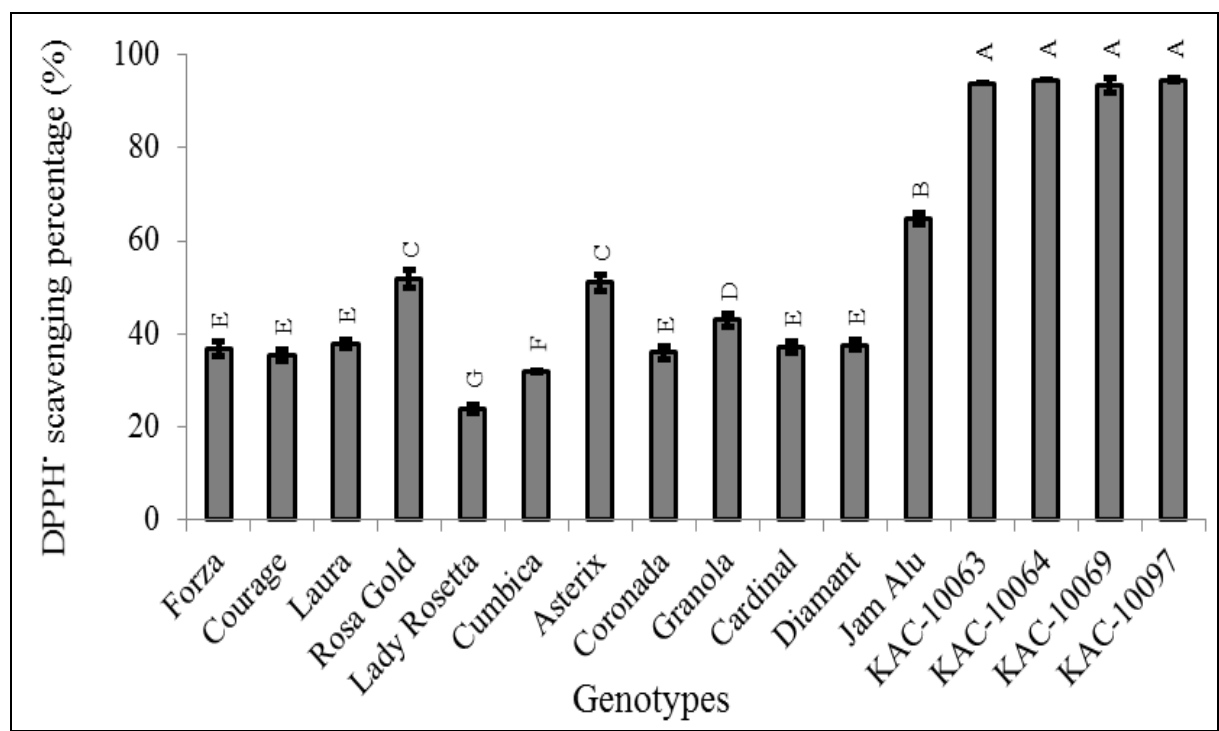

Fig. 2. Total antioxidant activity (DPPH scavenging \%) in sixteen potato genotypes. Vertical bars represent $\pm \mathrm{SE}$ values calculated from three replications; values in the columns with different letter(s) are significantly different at p $\leq \mathbf{0 . 0 5}$ by DMRT.

\section{Correlation analysis}

Our statistical analysis suggests antioxidant activity of the genotypes positively correlates to the content of carotenoids $\left(R^{2}=0.50\right)$, anthocyanins $\left(R^{2}=0.68\right)$ and flavonoids $\left(\mathrm{R}^{2}=0.68\right)$ suggesting that presence of these organic components have the great role to increase the antioxidant activity of potato genotypes (Fig. 3; a, b, c). In contrast, the antioxidant activity negatively correlates to the phenolics and ascorbic acid content of the genotypes (data not shown) although some demonstrations found positive relationship in that respect (Reyes et al, 2005). Moreover, our investigation found negative correlation between phenolics and carotenoids content (Fig. 3; d) supporting the higher carotenoids accumulation is responsible for lower phenolics content in the genotypes used in this study. The trend of this result is supported by the findings of Reddivari et al. (2007). This variation may be due to the lower accumulation of these two organic components in the genotypes used in this study (Table 1). The positive correlation between anthocyanin content and carotenoids was found in our experiment (Fig. 3; e), although Brown et al. (2007) found that as negative. The varied relationship among these organic components should be occurred due to the variation of genotypes and environment as well. 

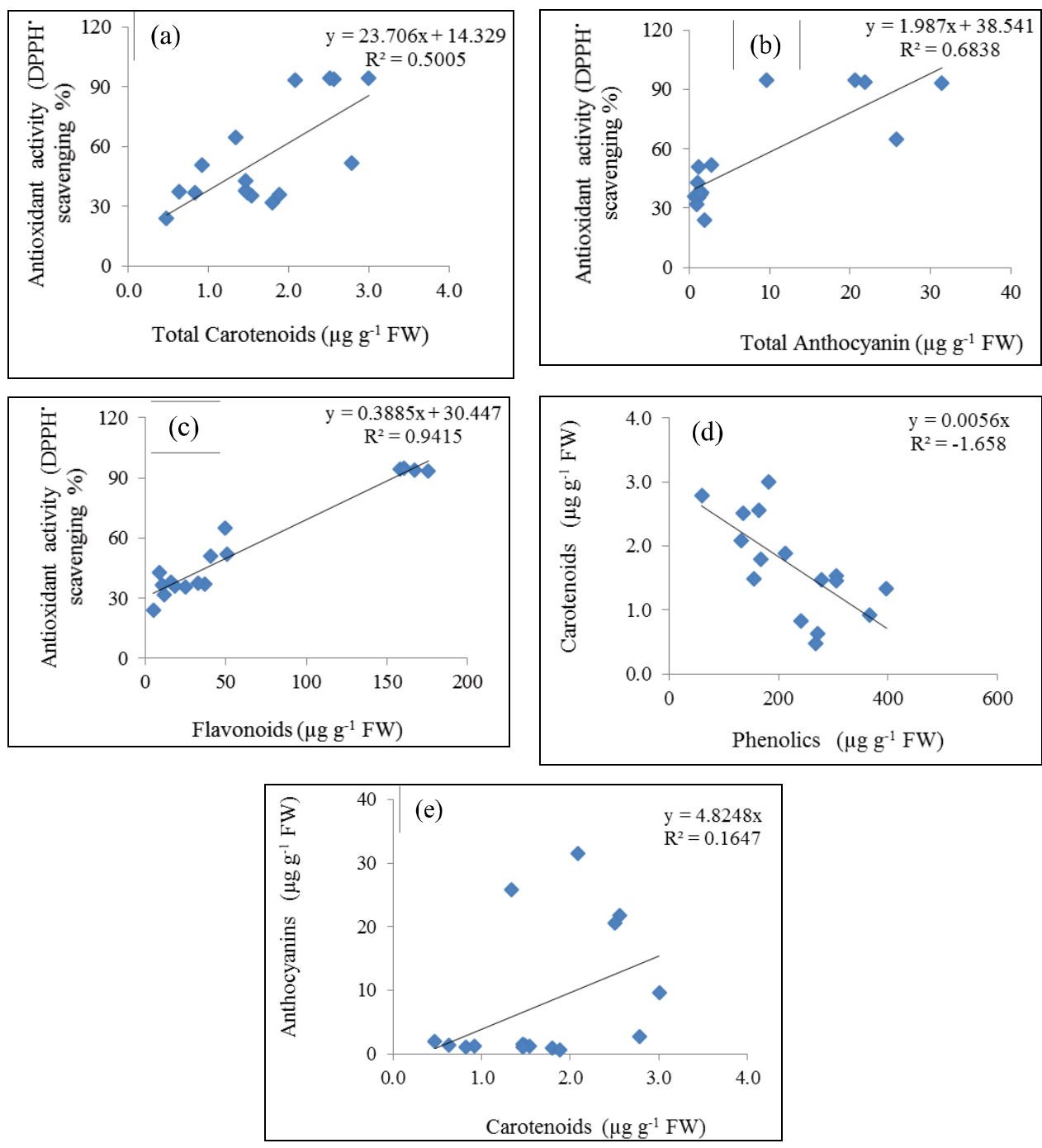

Fig. 3 Correlation of total (a) carotenoids, (b) anthocyanin, (c) flavonoids with DPPH radical scavenging activity (\%), and carotenoids content with (d) phenolics and (e) anthocyanin.

\section{Conclusion}

Based on the comparative biochemical analyses, it can be concluded that the purple fleshed genotypes KAC 10097, KAC 10063, KAC 10064, KAC 10069 and Jam Alu exhibited very high antioxidant potential that might be suitable for direct consumption as vegetables. Among the yellow fleshed genotypes, only Rosa gold should be as good candidate in terms of showing more or less better 
antioxidant potentials. However, the correlation analysis suggests that the antioxidant activity of the genotypes greatly depends on total carotenoids, anthocyanins and flavonoids content.

\section{References}

Andre, C. M., M. Ghislain, P. Bertin, M. Oufir, M. del Rosario Herrera, L. Hoffmann, J. F. Hausman, Y. Larondelle and D. Evers. 2007a. Andean potato cultivars (Solanum tuberosum L.) as a source of antioxidant and mineral micronutrients. $J$. Agric. Food Chem. 55(2): 366-378.

Andre, C. M., M. Oufir, C. Guignard, L. Hoffmann, J. F. Hausman, D. Evers and Y. Larondelle. 2007b. Antioxidant profiling of native Andean potato tubers (Solanum tuberosum L.) reveals cultivars with high levels of $\beta$-carotene, $\alpha$-tocopherol, chlorogenic acid, and petanin. J. Agric. Food Chem. 55(26): 10839-10849.

BBS. 2016. Government of the People's Republic of Bangladesh, Bangladesh Bureau of Statistics, Agriculture Wing. Estimates of Potato, 2015-16. Page: 2 http://203.112.218.65:8008/WebTestApplication/userfiles/Image/AgricultureWing/P otato-16.pdf

Brand-Williams, W., M. E. Cuvelier and C. L. W. T. Berset. 1995. Use of a free radical method to evaluate antioxidant activity. LWT- Food Sci. Technol. 28(1): 25-30.

Breithaupt, D. E. and A. Bamedi. 2002. Carotenoids and carotenoid esters in potatoes (Solanum tuberosum L.): new insights into an ancient vegetable. $J$. Agric. Food Chem. 50(24): 7175-7181.

Brown, C. R., D. Culley, C. P. Yang, R. Durst and R. Wrolstad. 2005. Variation of anthocyanin and carotenoid contents and associated antioxidant values in potato breeding lines. J. Am. Soc. Hortic. Sci. 130(2): 174-180.

Brown, C. R., D. Culley, M. Bonierbale and W. Amorós. 2007. Anthocyanin, carotenoid content, and antioxidant values in native South American potato cultivars. Hort. Science 42(7): 1733-1736.

Burgos, G., S. Auqui, W. Amoros, E. Salas and M. Bonierbale. 2009. Ascorbic acid concentration of native Andean potato varieties as affected by environment, cooking and storage. J. Food Compost. Anal., 22(6): 533-538.

FAOSTAT. 2016. Food and Agriculture Organization of the United Nations. http://www.fao.org/faostat/en/\#data/QC

Hamouz, K., J. Lachman, V. Pivec and B. Vokal. 1999. Influence of environmental conditions and way of cultivation on the polyphenol and ascorbic acid content in potato tubers. Rostlinna Vyroba-UZPI (Czech Republic).

Hesam, F., G. R. Balali and R. T. Tehrani. 2012. Evaluation of antioxidant activity of three common potato (Solanum tuberosum) cultivars in Iran. Avicenna J. Phytomed. 2(2): 79. 
Hughes, N. M. and W. K. Smith. 2007. Attenuation of incident light in Galax urceolata (Diapensiaceae): concerted influence of adaxial and abaxial anthocyanic layers on photoprotection. Am. J. Bot. 94(5): 784-790.

Jansen, G. and W. Flamme. 2006. Coloured potatoes (Solanum tuberosum L.)anthocyanin content and tuber quality. Genet. Resour. Crop Evol. 53(7): 1321.

Kapur, A., A. Hasković, A. Čopra-Janićijević, L. Klepo, A. Topčagić, I. Tahirović and E. Sofić. 2012. Spectrophotometric analysis of total ascorbic acid content in various fruits and vegetables. Bulletin of the Chemists and Technologists of Bosnia and Herzegovina. 38(4): 39-42.

Kaur, S. and P. Aggarwal. 2014. Evaluation of antioxidant phytochemicals in different genotypes of potato. Int. J. Eng. Res. Appl. 4(7): 167-172.

Kita, A., A. Bąkowska-Barczak, G. Lisińska, K. Hamouz and K. Kułakowska. 2015. Antioxidant activity and quality of red and purple flesh potato chips. LWT-Food Sci. Technol. 62(1): 525-531.

Kosieradzka, I., W. Borucki, I. Matysiak-Kata, J. Szopa and E. Sawosz. 2004. Transgenic potato tubers as a source of phenolic compounds. Localization of anthocyanins in the peridermis. J. Anim. Feed Sci. 13(2): 87-92.

Lachman, J., K. Hamouz, A. Hejtmánková, J. Dudjak, M. Orsák and V. Pivec. 2003. Effect of white fleece on the selected quality parameters of early potato (Solanum tuberosum L.) tubers. Plant Soil Environ. 49(8): 370-377.

Lachman, J., K. Hamouz, M. Šulc, M. Orsák, V. Pivec, A. Hejtmánková, P. Dvořák and J. Čepl. 2009. Cultivar differences of total anthocyanins and anthocyanidins in red and purple-fleshed potatoes and their relation to antioxidant activity. Food Chem. 114(3): 836-843.

Leszczynski, W. 2000. Jakosc ziemniaka konsumpcyjnego. Zywnosc Nauka Technologia Jakosc. 4(25): 5-26.

Nayak, B., J. D. J. Berrios, J. R. Powers, J. Tang and Y. Ji. 2011. Coloured potatoes (Solanum tuberosum L.) Dried for antioxidant-rich value-added foods. J. Food Process. Preserv. 35(5): 571-580.

Reddivari, L., A. L. Hale and J. C. Miller. 2007. Genotype, location, and year influence antioxidant activity, carotenoid content, phenolic content, and composition in specialty potatoes. J. Agric. Food Chem. 55(20): 8073-8079.

Reyes, L. F., J. C. Miller and L. Cisneros-Zevallos. 2005. Antioxidant capacity, anthocyanins and total phenolics in purple-and red-fleshed potato (Solanum tuberosum L.) genotypes. Am. J. Potato Res. 82(4): 271.

Singleton, V. L., R. Orthofer and R. M. Lamuela-Raventós. 1999. Analysis of total phenols and other oxidation substrates and antioxidants by means of folin-ciocalteu reagent. Academic press. In Methods in Enzymology. 299: 152-178. 
Teow, C. C., V. D. Truong, R. F. McFeeters, R. L. Thompson, K. V. Pecota and G. C. Yencho. 2007. Antioxidant activities, phenolic and $\beta$-carotene contents of sweet potato genotypes with varying flesh colours. Food chem. 103(3): 829-838.

Wojdyło, A., J. Oszmiański and R. Czemerys. 2007. Antioxidant activity and phenolic compounds in 32 selected herbs. Food chem. 105(3): 940-949.

Zhuang, X. P., Y. Y. Lu and G. S. Yang. 1992. Extraction and determination of flavonoid in ginkgo. Chin. Herb. Med. 23: 122-124. 
